
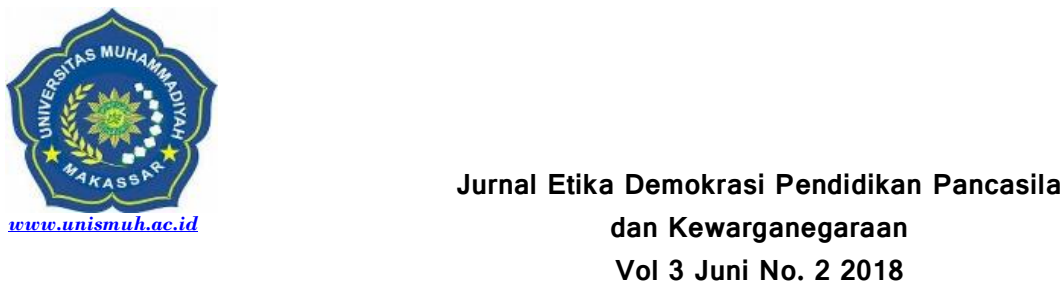

Jurnal Etika Demokrasi

\title{
Peran Pembelajaran Pembelajaran Pendidikan Pancasila dan Kewarganegaraan di Era Globalisasi dalam Mencegah Perilaku Menyimpang Siswa di SMAN II
}

\section{Kabupaten Bulukumba}

\author{
Andi Baso ${ }^{1)} \&$ Nasrun Hasan ${ }^{21}$ \\ Pendidikan Pancasila dan Kewarganegaraan FKIP Universitas Muhammadiyah Makassar ${ }^{1)}$ \\ Pendidikan Pancasila dan Kewarganegaraan FKIP Universitas Muhammadiyah Makassar ${ }^{2)}$ \\ andibaso@unismuh.ac.id ${ }^{1)}$ \& $\underline{\text { nasrunhasan@unismuh.ac.id } 2^{2}}$
}

\begin{abstract}
This study aims to determine the causes of deviant behavior, the role of learning Citizenship Education in the era of globalization in preventing the occurrence of deviant behavior of students in SMU 11 Bulukumba and the inhibiting factors of learning Citizenship Education in the era of globalization in preventing deviant behavior of students at SMU 11 Bulukumba. This type of research is qualitative descriptive research. This research was conducted at SMU 11 Bulukumba. Data sources used are primary data in the form of interviews and secondary data in the form of documents. The population in the study was the vice principal, BK teacher, PKn teacher and also students at SMU 11 Bulukumba. Data collection techniques used are interview techniques, observation and documentation. The research data were analyzed qualitatively descriptive. The results of this study indicate that (1) The causes of deviant behavior at SMAN 11 Bulukumba are social media, social, family and broken home, (2) Learning Citizenship Education has an important role in preventing students' deviant behavior. This is proven by using goals, learning materials, learning methods and strategies, good media and evaluation to make students not affected by the effects of globalization and (3) inhibiting factors for learning Citizenship Education is the mindset of students themselves, decreasing student motivation because more often dominated by users of social media such as Facebook during each class, so students become unfocused in learning the attitudes of material on Citizenship Education.
\end{abstract}

Keywords : Learning Citizenship Education, Globalization, Deviant Behavior.

\begin{abstract}
Abstrak. Penelitian ini bertujuan untuk mengetahui penyebab terjadinya perilaku menyimpang, peran pembelajaran Pendidikan Kewarganegaraan di era globalisasi dalam mencegah terjadinya perilaku menyimpang siswa di SMAN 11 Bulukumba dan faktor-faktor penghambat pembelajaran Pendidikan Kewarganegaraan di era globalisasi dalam mencegah perilaku menyimpang siswa di SMAN 11 Bulukumba. Jenis penelitian ini adalah penelitian deskriptif kualitatif. Penelitian ini dilaksanakan di SMAN 11 Bulukumba. Sumber data yang digunakan yaitu data primer berupa hasil wawancara dan data sekunder berupa dokumen-dokumen. Populasi dalam penelitian adalah wakil kepala sekolah, guru BK, guru PKn dan juga siswa di SMAN 11 Bulukumba. Teknik pengumpulan data yang digunakan yaitu teknik wawancara, observasi dan dokumentasi. Data hasil penelitian dianalisis deskriptif kualitatif. Hasil penelitian ini menunjukkan bahwa (1) Penyebab terjadinya perilaku menyimpang di SMAN 11 Bulukumba adalah media sosial, pergaulan, keluarga, dan broken home, (2) Pembelajaran Pendidikan Kewarganegaraan mempunyai peran penting dalam mencegah perilaku menyimpang siswa. Hal ini terbukti dengan menggunakan tujuan, materi pembelajaran, metode dan strategi pembelajaran, media dan evaluasi yang baik menjadikan siswa tidak terpengaruh terhadap dampak dari arus globalisasi dan (3) Faktor penghambat pembelajaran Pendidikan Kewarganegaraan adalah pola pikir siswa itu sendiri, menurunnya motivasi belajar siswa karena lebih sering didominasi oleh pengguna media sosial seperti facebook pada saat setiap jam pelajaran, sehingga siswa menjadi tidak fokus dalam mempelajari sikap materi Pendidikan Kewarganegaraan.

Kata kunci: Pembelajaran Pendidikan Kewarganegaraan, Globalisasi, Perilaku Menyimpang.
\end{abstract}




\section{PENDAHULUAN}

Pada hakikatnya pendidikan merupakan hak setiap individu anak bangsa untuk dapat menikmatinya. Pendidikan merupakan usaha secara sadar yang dilakukan oleh manusia agar dapat mengembangkan potensi dirinya melalui proses pembelajaran (Munib, dkk, 2007: 139). Keberadaan pendidikan yang sangat penting tersebut, telah diakui sekaligus memiliki legalitas yang kuat yang tertuang di dalam UUD 1945 pasal 31 Ayat 1 yang menyebutkan bahwa: "setiap warga negara berhak mendapatkan pendidikan".

Pendidikan formal dilaksanakan dalam dunia pendidikan nasional. Menurut Undang-Undang No. 20 Tahun 2003 tentang Sistem Pendidikan Nasional, pendidikan nasional bertujuan untuk berkembangnya potensi siswa agar menjadi manusia yang beriman dan bertaqwa kepada Tuhan Yang Maha Esa, berakhlak mulia, sehat, cakap, kreatif, mandiri dan menjadi warga negara yang demokratis dan bertanggung jawab.

Pendidikan di sekolah diharapkan dapat menciptakan manusia Indonesia yang berkualitas, manusia yang cerdas, berketerampilan dan berwatak. Cerdas dalam arti memiliki pengetahuan dan teknologi serta terdidik sehingga dapat menggunakan nalar dan intelektualnya. Berketerampilan artinya mampu melaksanakan berbagai tugas dan kewajibannya yang memerlukan keterampilan fisikal, sedangkan berwatak berarti memiliki kepribadian dan sikap yang sesuai dengan jiwa dan pandangan hidup bangsa.

Namun pada era globalisasi saat ini yang menghadapkan manusia pada perubahan perubahan yang tidak menentu justru terlihat bahwa sikap siswa mengalami penurunan yang begitu pesat.

Berbagai peristiwa yang sering terjadi pada para siswa akhir-akhir ini mengindikasikan mulai lunturnya jati diri di kalangan siswa dan pemuda yang berimbas terhadap penurunan moral. Faktor ini terjadi karena generasi muda sudah berada pada titik yang sangat mengkhawatirkan. Moralitas bangsa ini sudah lepas dari norma, etika agama, dan budaya luhur.
Saat ini kita merasakan bahwa banyak siswa bermasalah dengan sikapnya. Oleh karena itu, penanaman nilai moral, sikap dan perilaku individu harus dibentuk, dibangun, ditempa, dikembangkan dan dimantapkan melalui kebiasaan-kebiasaan baik sehingga muncul hasrat untuk berubah dalam diri siswa. Salah satu cara yang dapat dilakukan untuk mengurangi terjadinya kemorosotan moral bagi generasi muda bangsa saat ini adalah melalui pembelajaran Pendidikan Kewarganegaraan (PKn) sebagai bagian dari pendidikan karakter.

PKn sebagai mata pelajaran pendidikan moral merupakan suatu usaha membimbing perkembangan kepribadian siswa yang berlandaskan Pancasila. Oleh sebab itu, pendidikan PKn disetiap lembaga pendidikan harus tetap dilakukan secara terus menerus dan berkesinambungan. Pendidikan PKn juga sebagai sarana untuk mengembangkan potensi kepribadian siswa dengan mengangkat tema perkembangan IPTEK yang terjadi disekitar mereka.

Pada saat peneliti melakukan kegiatan Magang 1 di SMAN 11 Bulukumba yang dilaksanakan selama satu bulan yakni pada tanggal 1 Agustus 2015 hingga 30 Agustus 2015, selain melakukan kegiatan mengajar peneliti juga mengamati sikap siswa sehari-hari di sekolah. Dari hasil observasi tersebut, kenyataan terjadi bahwa sikap siswa di SMAN 11 Bulukumba mengalami penurunan yang sangat signifikan, terbukti dari banyaknya siswa yang bolos, keluar masuk pada saat PBM, bertutur kata tidak sopan, tidur di dalam kelas pada saat guru menjelaskan serta kurangnya rasa hormat siswa terhadap guru. Hal ini dapat kita lihat siswa menganggap guru adalah temannya sehinggga tidak ada lagi batasan antara mereka. Dari permasalahan di atas, peneliti menyimpulkan bahwa cukup rendah sikap moral siswa di SMAN 11 Bulukumba.

\section{METODE PENELITIAN}

Jenis penelitian ini adalah penelitian deskriptif dengan pendekatan kualitatif. Penelitian ini dilaksanakan di SMAN 11 Bulukumba yang beralamat di Jln. Hasan Sulaeman No.7 
Bontotangnga, Kecamatan Bontotiro, Kabupaten Bulukumba. Sumber data yang digunakan yaitu data primer berupa hasil wawancara dan data sekunder berupa dokumen-dokumen. Populasi dalam penelitian adalah wakil kepala sekolah, guru BK, guru PKn dan juga siswa di SMAN 11 Bulukumba. Sampel penelitian ini yaitu 1 orang wakil kepala sekolah urusan kurikulum, 1 orang wakil kepala sekolah urusan kesiswaan, 1 orang guru BK, 2 orang guru PKn dan 3 orang siswa di SMAN 11 Bulukumba. Teknik pengumpulan data yang digunakan yaitu teknik wawancara, observasi dan dokumentasi. Data hasil penelitian dianalisis deskriptif kualitatif.

\section{PEMBAHASAN}

\section{Perilaku Menyimpang di SMAN 11 Bulukumba}

Hasil penelitian yang dilakukan menunjukkan bahwa ada 4 yang menjadi penyebab degradasi moral di SMAN 11 Bulukumba, yakni media sosial, pergaulan, kurangnya perhatian dari orang tua, serta perceraian orang tua.

Media sosial sebagai salah satu bentuk kemajuan teknologi komunikasi dan informasi memungkinkan pengguna berbagi, berinteraksi, berkomunikasi dengan pengguna lain. Pada media sosial siswa dapat melakukan berbagai bentuk pertukaran, kolaborasi dan saling berkenalan. Dengan berbagai fasilitas yang disediakan seperti whatsapp, facebook, instagram dan lain-lain dapat membawa pengaruh negatif pada siswa.

Selain itu, pergaulan juga merupakan pemicu menurunnya moral siswa. Pergaulan yang dimaksud adalah pengaruh teman sebaya. Teman sebaya mempunyai peran bagi perkembangan perilaku sosial anak. Teman sebaya memberi kesempatan untuk berinteraksi dengan orang di luar anggota keluarganya. Pergaulan teman sebaya dapat mempengaruhi perilaku. Pengaruh tersebut dapat berupa pengaruh positif dan dapat pula pengaruh negatif. Pengaruh positif yang dimaksud adalah ketika individu tersebut bersama teman-teman sebayanya melakukan aktivitas yang bermanfaat seperti membentuk kelompok belajar dan patuh pada norma-norma dalam masyarakat.
Sedangkan pengaruh negatif yang dimaksudkan dapat berupa pelanggaran terhadap norma-norma sosial, dan pada lingkungan sekolah pelanggaran terhadap peraturan sekolah. Hal ini sejalan dengan pendapat Coplan \& Arbeau (dalam Santrock, 2011: 122) yang menyatakan bahwa frekuensi interaksi teman sebaya yang dilakukan selama bertahun-tahun baik itu positif maupun negatif terjadi cukup signifikan. Anak-anak banyak menghabiskan waktu untuk berinteraksi dengan teman sebaya.

Penyebab lainnya adalah pengaruh keluarga. Keluarga adalah tempat pendidikan pertama dan utama bagi anak, mereka berada dalam keluarga sejak dalam kandungan sampai menjelang pernikahan. Oleh karena itu peranan keluarga sangat penting dalam perjalanan seorang anak. Dalam pedoman penyelenggaraan parenting Kemdikbud 2012, dinyatakan bahwa keluarga sebagai lembaga pendidikan informal dilindungi dalam Undang-Undang Sistem Pendidikan Nasional. Menurut Ki Hadjar Dewantara, keluarga adalah lingkungan pendidikan yang pertama dan utama. Dengan demikian, peran keluarga dalam hal pendidikan bagi anak, tidak dapat tergantikan sekalipun anak telah dididik di lembaga pendidikan formal maupun nonformal. Pendidikan dalam keluarga merupakan hal yang sangat penting, karena disinilah dibentuk dasar karakter seorang anak. Apakah anak tersebut akan dibentuk untuk memiliki karakter yang positif ataupun negatif, keluargalah yang menentukannya.

Keluarga yang memiliki hubungan tidak harmonis dan penuh konflik diantara anggota keluarganya juga dapat menimbulkan masalah mental bagi anak sehingga anak memiliki kecemasan jiwa dan konflik batin. Menurut Undang-Undang Nomor 20 Tahun 2003 tentang Sistem Pendidikan Nasional bahwa pendidikan nasional berfungsi untuk mengembangkan potensi siswa agar menjadi manusia yang beriman serta menjadi warga negara yang demokratis serta bertanggung jawab. Dengan ini bahwa Pendidikan Kewarganegaraan dapat dijadikan tempat bagi siswa dalam mengembangkan kemampuan dan 
potensi pada diri siswa sehingga siswa dapat menjadi manusia yang berkarakter. Hal tersebut dapat memposisikan pembelajaran Pendidikan Kewarganegaraan sebagai pembentukan karakter. Hasil penelitian ini sejalan dengan penelitian terdahulu di antaranya penelitian yang dilakukan oleh Ramdani (2016) peran pembelajaran Pendidikan Kewarganegaraan sebagai salah satu mata pelajaran dalam lingkup pendidikan formal dapat digunakan sebagai wadah pembentukan karakter bagi siswa.

\section{Peran Pembelajaran Pendidikan}

Kewarganegaraan di Era Globalisasi dalam Mencegah Terjadinya Degradasi Moral Siswa di SMAN 11 Bulukumba

Dalam menghadapi tantangan globalisasi yang ditandai dengan kemajuan teknologi informasi, pembelajaran Pendidikan Kewarganegaraan memiliki peranan penting dalam mencegah degradasi moral. Era globalisasi memang tidak dapat dipungkiri telah menjadi bagian dari dunia pendidikan termasuk di SMAN 11 Bulukumba. Globalisasi pada dasarnya bagaikan pisau bermata dua. Bisa memberikan manfaat, akan tetapi disisi lain ia juga mendatangkan mudarat bagi siswa sehingga telah tejadi pergesekan nilai yang sangat signifikan. Salah satu contohnya adalah siswa membangkang terhadap apa yang disampaikan oleh guru. Untuk itu dibutuhkan peran pembelajaran Pendidikan Kewarganegaraan dalam mencegah degradasi moral tersebut.

Seperti halnya di SMAN 11 Bulukumba, pada pelaksanaan pembelajaran di sekolah sangat berpengaruh positif bagi siswa karena dalam proses pembelajaran guru menggunakan komponen-komponen pembelajaran yang sangat baik. Komponen-komponen yang dimaksud adalah tujuan, materi pembelajaran, metode dan strategi pembelajaran, media dan evaluasi. Dengan komponen-komponen tersebut, maka proses pembelajaran menjadi terarah dan fokus pada target yang akan dituju serta diharapkan meningkatkan motivasi pendidik maupun siswa dalam proses belajar dan mengajar (Sanjaya, 2010: 58).
Disamping itu penggunaan beberapa metode yang bervariasi pada setiap pembelajaran di kelas sangat efektif dalam menciptakan suasana kelas yang kondusif bagi siswa sehingga menimbulkan intensitas belajar yang baik. Adapun beberapa metode pembelajaran yang bisa digunakan dalam proses pembelajaran di kelas menurut Sanjaya. Metode tersebut dapat digunakan untuk menciptakan suasana kelas yang kondusif dan terarah sehingga dapat tercapai suatu tujuan dalam proses pembelajaran

Pendidikan Kewarganegaraan di SMAN 11 Bulukumba. Selain itu guru memberikan sikap keteladanan bagi siswa seperti memberikan sanksi kepada siswa, mentaati peraturan sekolah (tata tertib), melaksanakan program yang diberikan oleh pihak sekolah, sehingga siswa mampu bersikap baik dan mampu mendisiplinkan waktu dalam belajar sehingga degradasi moral dapat diatasi dengan baik.

Pencapaian keberhasilan pembelajaran Pendidikan Kewarganegaraan di era globalisasi dalam mencegah degradasi moral di SMAN 11 Bulukumba ini tentunya mengalami beberapa hambatan atau kendala yang dialami oleh guru Pendidikan Kewarganegaraan. Berdasarkan hasil penelitian bahwa adanya penurunan terhadap motivasi siswa yang disebabkan oleh ketidaknyamanan di kelas. Maka dari itu strategi yang digunakan dalam pembelajaran haruslah tepat karena strategi pembelajaran sangat penting dalam menunjang proses pembelajaran. Sebagaimana dijelaskan oleh Kemp (Sanjaya, 2010: 126) menjelaskan pengertian strategi pembelajaran yakni: "suatu kegiatan pembelajaran yang harus dikerjakan guru dan siswa agar tujuan pembelajaran dapat tercapai secara efektif dan efisien. Strategi menunjukkan pada sebuah perencanaan untuk mencapai tujuan"

Pada dasarnya tidak ada strategi pembelajaran yang dipandang paling baik, karena setiap strategi pembelajaran saling memiliki keunggulan masing-masing. Maka dari itu, seorang pendidik harus mampu memilih strategi yang akan digunakan dalam proses pembelajaran sehingga 
dapat menunjang proses keberhasilan dalam belajar. Selain itu, pengaruh globalisasi tersebut dapat menjadi kendala bagi pembelajaran Pendidikan Kewarganegaraan, karena dapat berpengaruh pada pola pikir siswa itu sendiri yang akan mengakibatkan disiplin waktu belajar menjadi berkurang.

Maka dari itu dalam menunjang proses keberhasilan dalam pembelajaran maka dibutuhkan beberapa strategi pembelajaran yang tepat dan seimbang agar dapat mencapai tujuan pembelajaran. Menurut Djamarah dan Zain (2010: 5-6) ada empat strategi dasar dalam belajar mengajar. Berdasarkan penjelasan di atas dapat dikatakan bahwa suatu strategi pembelajaran yang tepat adalah harus seimbang yakni dengan memperhatikan isyarat-isyarat seperti yang disebutkan di atas. Seimbang disini berarti harus tepat dalam mempertimbangkan penggunaan pendekatan, metode dan unsur lain yang dapat bermanfaat untuk keberhasilan belajar mengajar. Kemudian kendala selanjutnya ada pada pengaruh yang ditimbulkan oleh media sosial seperti facebook. Menurut guru Pendidikan Kewarganegaraan bahwa facebook dapat dikatakan sebagai media sosial yang dapat menciptakan dunia yang bebas dan luas artinya facebook tersebut dapat diakses kapan saja dan dimana saja tanpa ada yang membatasi ruang dan waktu, maka dari itu facebook sebagai media sosial pasti memiliki dampaknya bagi siswa baik itu dampak positif maupun dampak negatif.

\section{Faktor-Faktor Penghambat Pembelajaran Pendidikan Kewarganegaraan di Era Globalisasi dalam Mencegah Degradasi Moral Siswa di SMAN 11 Bulukumba}

Berdasarkan hasil penelitian yang telah diperoleh ada tiga kendala dalam pembelajaran Pendidikan Kewarganegaraan yaitu yang pertama kendala yang berasal dari pola pikir siswa itu sendiri yang didasari rasa suka dan tidaknya terhadap pembelajaran Pendidikan Kewarganegaraan. Kendala selanjutnya ada pada pengaruh dari media sosial seperti facebook yang akan melahirkan dampak positif dan negatif terhadap siswa. Kendala yang dihadapi pembelajaran Pendidikan Kewarganegaraan pada saat di kelas adalah menurunnya motivasi belajar siswa karena lebih sering didominasi oleh pengguna facebook pada saat setiap jam pelajaran, sehingga siswa menjadi tidak fokus dalam mempelajari setiap materi Pendidikan Kewarganegaraan.

\section{KESIMPULAN}

Berdasarkan hasil penelitian dan pembahasan disimpulkan bahwa penyebab terjadinya degradasi moral peserta didik di SMAN 11 Bulukumba adalah media sosial, teman sebaya, kurangnya perhatian orang tua dan broken home. Oleh karena itu, untuk mencegah terjadinya degradasi moral disinilah pentingnya peran pembelajaran Pendidikan Kewarganegaraan dalam mencegah merosotnya moral peserta didik dengan menggunakan tujuan, materi pembelajaran, metode dan strategi pembelajaran, media dan evaluasi yang baik sehingga siswa tidak terpengaruh terhadap dampak yang dihasilkan oleh arus globalisasi. Kendala yang dihadapi pembelajaran Pendidikan Kewarganegaraan pada saat di kelas adalah pola pikir siswa itu sendiri, menurunnya motivasi belajar siswa karena lebih sering didominasi oleh pengguna media sosial seperti facebook pada saat setiap jam pelajaran, sehingga siswa menjadi tidak fokus dalam mempelajari setiap materi Pendidikan Kewarganegaraan.

\section{DAFTAR PUSTAKA}

[1] Arikunto, Suharsimi. (2006). Prosedur Penelitian Suatu Pendekatan Praktek. Yogyakarta: Rineka Cipta.

[2] Azra, Zamroni. (2002). Demokrasi Hak Asasi Manusia. Bandung: PT Remaja Rosdakaraya.

[3] Branson, Margaret, dkk. (1999). "Belajar "Civic Education" dari Amerika". Yogyakarat: Lkis dan TAF.

[4] Branson, Margaret, dkk. (1999). "Belajar "Civic Education" dari Amerika". Yogyakarat: Lkis dan TAF.

[5] Cholisin. (2000). IKn dan PKn. Jakarta: Universitas Terbuka.

[6] Hamisa, Wilda. (2013). Peranan Pembelajaran Pendidikan Kewarganegaraan dalam Menanamkan Sikap Nasionalisme Siswa di Era Globalisasi. Purwokerto: Jurusan Pendidikan Pancasila dan Kewarganegaraan. 
[7] M. Branson. (1999). Belajar Civic Education dari Amerika. Yogyakarta: Lembaga Kajian Islam dan Sosial.

[8] Moleong, Lexy. (2002). Metode Penelitian Kualitatif. Bandung: PT. Remaja Rosdakarya.

[9] Moleong, Lexy. (2007). Metodologi Penelitian Kualitatif Edisi Revisi. Bandung: PT. Remaja Rosdakarya.

[10] Munib, Achmad, dkk. (2007). Pengantar IImu Pendidikan. Semarang: UNNES Press.

[11] Nugroho, Heru. (2001). Negara, Pasar, dan Keadilan Sosial. Yogyakarta: Pustaka Pelajar.

[12] Peraturan Pemerintah No.19 Tahun (2005) tentang Standar Nasional Pendidikan.

[13] Permendiknas No. 22 Tahun (2006) Tentang Standar Isi Pendidikan Nasional.

[14] Rachman, Maman. (1999). Strategi dan LangkahLangkah Penelitian. Semarang: IKIP Semarang Press.

[15] Rozak, Abdul, dkk. (2008). Pendidikan Kewarganegaraan (Civic Education). Kencana: Jakarta.

[16] Sakman. (2016). Peran Pendidikan Kewarganegaraan di Era Globalisasi dalam Mencegah Degradasi Moral. Jurnal Pendidikan (Online). (http://jurnal-online-jpips-desember2016-peran-pendidikan-kewarganegaraan-di-eraglobalisasi-dalam-mencegah-degradasi-moral.ac.id) diakses tanggal 25 Desember 2018.

[17] Soemantri, Muhammad Numan. (2001). Menggagas Pembaharuan Pendidikan IPS. Bandung: PT. Remaja Rosdakarya.

[18] Sugiyono. (2013). Metode Penelitian Kuantitatif Kualitatif dan R\&D. Bandung: Alfabeta.

[19] Sunarso, dkk. (2008). Pendidikan Kewarganegaraan untuk Perguruan Tinggi. Yogyakarta: UNY Press.

[20] Syarbaini, Syahrial. (2010). Implementasi Pancasila melalui Pendidikan Kewarganegaraan. Yogyakarta: Graha Ilmu.

[21] Ubaedillah. (2015). Pancasila, Demokrasi, HAM, dan Mayarakat Madani. Jakarta: Kencana.

[22] Ubaedillah. (2015). Pendidikan Kewarganegaraan (Civic Education) : Pancasila, Demokrasi, dan Pencegahan Korupsi. Jakarta: Prenada Media Group.

[23] Undang-Undang Dasar (1945) Hasil Amandemen.

[24] Undang-Undang Dasar Pasal 31 Ayat 1

[25] Undang-Undang No. 20 Tahun (2003) Tentang Sistem Pendidikan Nasional.

[26] Winarno. (2013). Pembelajaran Pendidikan Kewarganegaraan. Jakarta: PT. Bumi Aksara.

[27] Winataputra, Udin S. 2007. Civic Education, Konteks, Landasan, Bahan Ajar dan Kultur Kelas. Bandung: UPI.

[28] Wuryan, Sri dan Syaifullah. 2009. IImu Kewarganegaraan (Civics). Bandung: Laboratorium Pendidikan Kewarganegaraan. 